\title{
JOACHIM RITTER \\ (1903-1974)
}

VARGA PÉTER ANDRÁS

Német filozófus, a róla elnevezett kortárs filozófiai iskola alapítója. Egyetemi pályafutásának elején Cassirer tanítványa volt Hamburgban, 1946-tól a münsteri egyetem filozófiaprofesszora. 1950 és 1953 között vendégprofesszor volt Isztambulban, ahol nagy hatást gyakorolt rá az európaizálás, illetve a kemalista szekularizáció programjának közelről történő megfigyelése. A német filozófia II. világháborút követő reneszánszában Ritter tanítványi köre az egyik legjelentősebb filozófiai iskolaként rajzolódott ki (különösen retrospektív nézőpontból), amely főként a közértelmiségi szerepvállalás, a Német Szövetségi Köztársaság politikai támogatása tekintetében a Frankfurti iskola (lásd Theodor Adorno, Habermas) ellenpólusát alkotta, ami miatt a Ritter-iskolát néha a polgáriasság (Bürgerlichkeit) filozófusaiként is aposztrofálják. A XIX. századi hegelianizmus osztályozásához használt tipológiához hasonlóan szokás a Ritter-iskolát felosztani balszárnyra (pl. a szocialista politikus és politológus Jürgen Seifert [1928-2005], ill. a marxizmushoz közel álló filozófus Hans Jörg Sandkühler [1940-]) és jobbszárnyra (pl. a keresztény-konzervatív filozófus Günter Rohrmoser [1927-2008], valamint az életének önkezével véget vető nacionalista politológus Bernard Willms [1931-1991]). Ehhez, a XIX. századi hegelianizmus struktúrájától némileg eltérően, az iskola lényegi képviselőit felvonultató középszárny csatlakozik, amelynek reprezentánsai mindenekelőtt a polgári konzervatív filozófus és tudománypolitikus Hermann Lübbe (1926-), a hermeneutikai filozófiát szkeptikus attitüdjével és brilliáns stílusmüvészetével (ún. „transzcendentál-szépirodalom,” Transzendental-Belletristik) megújító Odo Marquard (1928-2015), valamint a katolikus filozófus Spaemann.

Intézménytörténeti szempontból az iskola kohézióját eleinte Ritter híres (poszt)doktori szemináriuma, a Collegium philosophicum biztosította (informálisan a tanítványok eszmecseréi a legendás münsteri Café Schucanban), később az 1960-as évektől az - először Gadamer társ-föszerkesztésében - kiadni tervezett, majd 1971 és 2004 között tizenkét kötetben megjelent Historisches Wörterbuch der Philosophie („A filozófia történeti szótára”) bizonyult a Ritter-iskola fokális pontjának. Arról, hogy a lexikonvállalkozás nem pusztán az iskola intézményi összetartását volt hivatott garantálni, tanúskodnak Ritter programszerü megfogalmazásai, 
pl.: „A rendszer és a filozófiatörténet közti válaszfal áteresztővé válik” (Zeitschrift für philosophische Forschung 18/4 [1964], 706). Ugyanakkor nem világos, miként sikerült készpénzre váltani a fogalomtörténet-írást első filozófiává emelő ambíciózus metafilozófiai programot, miközben már a Ritter életében megjelent három kötetnél sem érvényesítettek doktriner elvárásokat (ezért sem szerepelt a „fogalomtörténeti” jelző a lexikon címében), a későbbi főszerkesztők pedig csak egy pragmatikus koncepció jegyében tudták a vállalkozást sikerre vinni.

Ritter életében keveset publikált, s a Ritter-iskolához tartozó Robert Spaemann sokat idézett visszaemlékezése szerint a Collegium Philosophicum egységét nem módszertani vagy doktrinális alap, hanem „a kérdésfeltevéseknek a közös volta” biztosította (Frankfurter Allgemeine Zeitung, 2003. április 3., 39), nevezetesen az „emancipáció," illetve „a szubsztancialitás és szubjektivitás viszonya drámájának” (uo.) kontextusában történő értelmezés (habár a kérdések között is volt egy tabutéma: „Miért akarta Hegel, hogy Fichte mellé temessék?” [uo.]; ami jól kifejezi Ritter averzióját a lineáris-kumulatív rendszeralkotással szemben). Ugyan a módszertanilag felvilágosult filozófiatörténet írásától nem lehet idegen a felismerés, hogy a filozófiai iskolaközösségek tényleges egységét inkább „családi hasonlóságok” (lásd Wittgenstein) rendszere biztosítaná, ám ebben inkább a katolikus filozófus Spaemann különutasságának megmutatkozását érdemes látnunk, legalábbis megjelölhető a Ritter-iskola központi teoretikus eleme a kompenzációelméletben, amely az emancipáció és az elidegenedés dialektikáját próbálja leírni a hegeli szintézisfogalom totalizáló aspektusának elkerülésével. Megjegyzendő, hogy inkább Ritter és a Ritter-iskola középszárnya volt képes e kreatív feszültség nyitva tartására, míg a jobbszárny reprezentánsai - pl. egy antimodernista, a saját korára mint dekadenciára tekintő vallásfogalom, illetve egy kultúrnacionalizmus révén - és a balszárny képviselői - pl. egy nyugati marxista emancipációfogalom, illetve egy kifejezetten dialektikus-materialista történelemfelfogás segítségével - hajlamosak voltak e dialektika rövidre zárására.

Amint a ritteri kompenzációelmélet 1961-ből származó klasszikus szöveghelye mutatja - „a társadalomnak feltétlenül szüksége van egy szervre, mely kompenzálja történelemnélküliségét”, amely utóbbi ugyanakkor „konstitutív és megszüntethetetlen" számára (Metaphysik und Politik. Studien zu Aristoteles und Hegel, 2003, 399, magyarul uö: Szubjektivitás. Válogatott tanulmányok, 2007, 104) -, a kompenzációelmélet különösen jól alkalmazható a bölcsészettudományok (más terminussal szellemtudományok) genezisének és legitimitásának filozófiai igazolására; sőt Ritter elmélete talán az egyetlen, ami a legitimációs feladatra nem a tág értelemben vett kritikai elmélet (marxizmus) felől vállalkozik, ugyanakkor - szemben a bölcsészettudományok céljának valamiféle kultúrpesszimista felfogásával - számot vet e tudományok sajátságosan modern eredetével is (gondoljunk például a müemlékvédelem esetére). 
A ritteri kompenzációfogalom szisztematikus kifejtését Hermann Lübbének köszönhetjük egy, a modernitás jelenségei iránt érzékeny, common sense kultúrfilozófia jegyében (vö. pl. Im Zug der Zeit. Verkürzter Aufenthalt in der Gegenwart [„Az idő sodrában. Rövidített tartózkodás a jelenben”], 2003). Lübbe szerint a kompenzáció mechanizmusa nem a jelenkor valamiféle történetietlenségéből ered, hanem éppen a modernitás történeti jellemzőjéből: „A civilizatorikus modernitás minden hasonlíthatatlanul lassabban fejlődő eredeti kultúrát beborít, mivel egy történetileg példátlan fejlödési dinamikával rendelkezik" (i. m., 286). Lübbe egyaránt elutasítja a modernitásnak a lineáris történeti teleológia sémája szerinti értelmezését (melyet Popper némileg félrevezető módon historicizmusnak nevezett), mégpedig a haladás által okozott folyamatos komplexitásnövekedés elleni pragmatikus-szkeptikus, az emberi végességre hivatkozó érvek miatt. Amint Lübbe gondolkodótársa, Marquard fogalmazott, „Nem a változatlanul maradás, hanem a megváltoztatás szorul igazolásra: a bizonyítási teher a változtatni akarót terheli” (Abschied vom Prinzipiellen. Philosophische Studien [„Búcsú az elvitől. Filozófiai tanulmányok”], 1981, 123). A kompenzáció mechanizmusa tehát a „tudományos-technikai civilizáció [...] történetileg szinguláris történetiességének" talaján születik meg (Lübbe, i. m., 287), pontosabban a kompenzációelmélet „a szellemtudományok kompenzatorikus teljesítményeire való” ráutaltságunk (uo.) tényét kívánja magyarázni, azaz a bölcsészettudományok (szellemtudományok) transzcendentális konstitúcióelméleteként tekinthető.

A kompenzációelmélet népszerüsítése a szintén a Ritter-iskola középszárnyához sorolható német jogfilozófus és alkotmánybíró Ernst-Wolfgang Böckenförde (1930-2019) nevéhez füződő Böckenförde-dilemmának (vagy Böckenförde-paradoxonnak) köszönhetö, miszerint „a szabad szekuláris állam olyan elöfeltevésekre épül, melyeket maga nem tud garantálni" (Recht, Staat, Freiheit. Studien zur Rechtsphilosophie, Staatstheorie und Verfassungsgeschichte [„Jog, állam, szabadság. Tanulmányok a jogfilozófia, az államelmélet és az alkotmánytörténet köréből’], 1976, 112). A szekularizáció mélyén rejlő, ilyen természetű nem-lezárt dialektika feltételezése nemcsak a világnézetek kortárs dialógusában (lásd különösen Habermas és Joseph Ratzinger [XVI. Benedek] vitáját: Dialektik der Säkularisierung: Über Vernunft und Religion, 2005, magyarul A szabadelvü állam morális alapjai, 2007) kapott szerepet, hanem aktualitásra tehet szert a mai világjárvány idején a Böckenförde gondolatmenetéhez csatlakozó, kevesebbszer figyelembe vett kérdés révén, ami arra irányul, hogy miként állhatja meg helyét ez az állam a válsághelyzetben; még akkor is, ha eközben az állam szekuláris önmegalapozásának azon, Böckenförde által szintén megfontolt lehetősége mutatkozik meg, miszerint a pre-szekuláris előfeltevések helyett a modern állam a „polgárai eudaimonikus életelvárásainak betöltési garanciájaként" próbált új szerepet találni magának (Böckenförde, i. m., 113), s a krízisben éppen ezen ígéret végrehajthatósága vált kérdésessé. 
Az a historizálódási folyamat, amely során retrospektív módon kirajzolódik a Ritter-iskola mint a német félmúlt egyik legjelentősebb filozófiai alakzata, örvendetes módon az elérhető Ritter-szövegek körének bővülésével is járt, köztük Ritter egy kéziratban maradt, 1931-ből származó Dilthey-kritikájának megjelenésével (Über die antinomische Struktur der geisteswissenschaftlichen Geschichtsauffassung bei Dilthey [„Dilthey szellemtudományi történelemfelfogásának antinomikus szerkezetéről"], Dilthey Jahrbuch 9 [1994/1995], 183-206), ami még Ritter marxizmushoz közeli alkotói korszakához köthető. Amint ez a fejlödéstörténetileg kulcsfontosságú szöveg mutatja, Ritter aktívan kapcsolódott Hegelhez: egyrészt azt remélte, Dilthey életfogalma révén, amely a hegeli abszolút szellem helyett az objektív szellemet, a történeti világ objektivációs mechanizmusait helyezi a középpontba, meghaladhatók Hegel klasszikus metafizikai elköteleződései; ugyanakkor „visszaesést” is diagnosztizált Diltheynél a „Hegel által elért állásponthoz” képest (i. m., 190), amennyiben dualizmus jelenik meg nála a szellemi-történeti világ és az annak forrásaként szolgáló világtalány (az élet alapja) között. Ez a dualizmus tudatos formájában Dilthey késői világnézet-filozófiájának történelemelemzése szerint a modernitással, a szekularizáció értelmiségének kialakulásával lép elő. „Vajon a történeti világ kompenzatorikus funkciójában az értelmiségi számára nem a saját történeti hatástalanságának tudata rejlik?” - kérdezte , ekkor még a történelmi cselekvés lehetőségének egy marxista ideálja felől (i. m., 198). Ez a korai, különleges eszmetörténeti helyzetben született Ritter-szöveg jól mutatja, hogy a „kompenzatorikus teljesítmény” (i. m., 203) elképzelése eredetileg Ritternél is a szekularizáció problémájának horizontján fogalmazódott meg, ugyanakkor nem függetlenül attól a késői marxizmustól örökölt kérdésfeltevéstől sem, ami a történeti fejlődés menetére specifikusan az értelmiség feladata és cselekvési lehetőségei szempontjából mutat rá. Innen tekintve a Ritter-iskola organikus ívet rajzol ki tagjainak a II. világháború utáni közértelmiségi szerepvállalásáig és a modernitás dilemmáira irányuló tágabb reflexióiig, egyúttal azt a közös eszmetörténeti keretet is felvázolva, amiben a Ritter-iskola a félkortárs nyugatnémet filozófia más gondolati alakzataival osztozik.

\section{TOVÁBBI IRODALOM}

Hacke, Jens: Philosophie der Bürgerlichkeit: Die liberalkonservative Begründung der Bundesrepublik (2008).

Schweda, Mark: Joachim Ritter und seine Schule zur Einführung (2015).

Szalay Zoltán - Zuh Deodáth (szerk.): Beszélgetés Odo Marquarddal. Századvég, 85 (2017), 143-157. 